\title{
Epicatechin induces NF-кB, activator protein-1 (AP-1) and nuclear transcription factor erythroid 2p45-related factor-2 (Nrf2) via phosphatidylinositol-3-kinase/protein kinase B (PI3K/AKT) and extracellular regulated kinase (ERK) signalling in HepG2 cells
}

\author{
Ana Belén Granado-Serrano ${ }^{1}$, María Angeles Martín ${ }^{1}$, Guy Haegeman ${ }^{2}$, Luis Goya ${ }^{1}$, Laura Bravo ${ }^{1}$ \\ and Sonia Ramos ${ }^{1 *}$ \\ ${ }^{1}$ Department of Metabolism and Nutrition, Instituto del Frí-ICTAN, Consejo Superior de Investigaciones Científicas (CSIC), \\ José Antonio Novais 10, 28040 Madrid, Spain \\ ${ }^{2}$ Laboratory of Eukaryotic Gene Expression and Signal Transduction (LEGEST), Department of Physiology, \\ University of Ghent, K. L. Ledeganckstraat 35, B-9000 Ghent, Belgium
}

(Received 23 March 2009 - Revised 22 July 2009 - Accepted 23 July 2009 - First published online 2 November 2009)

\begin{abstract}
The dietary flavonoid epicatechin has been reported to exhibit a wide range of biological activities. The objective of the present study was to investigate the time-dependent regulation by epicatechin on the activity of the main transcription factors (NF- $\mathrm{kB}$, activator protein-1 (AP-1) and nuclear transcription factor erythroid 2p45-related factor (Nrf2)) related to antioxidant defence and survival and proliferation pathways in HepG2 cells. Treatment of cells with $10 \mu \mathrm{M}$-epicatechin induced the NF- $\mathrm{BB}$ pathway in a time-dependent manner characterised by increased

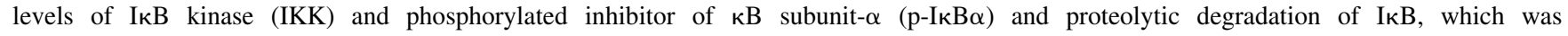
consistent with an up-regulation of the NF- $\mathrm{BB}$-binding activity. Time-dependent activation of the AP-1 pathway, in concert with enhanced c-Jun nuclear levels and induction of Nrf2 translocation and phosphorylation were also demonstrated. Additionally, epicatechin-induced NF- $\mathrm{B}$ and Nrf2 were connected to reactive oxygen species intracellular levels and to the activation of cell survival and proliferation pathways, being phosphatidylinositol-3-kinase/protein kinase B (PI3K/AKT) and extracellular regulated kinase (ERK) associated to Nrf2 modulation and ERK to NF- $\kappa \mathrm{B}$ induction. These data suggest that the epicatechin-induced survival effect occurs by the induction of redox-sensitive transcription factors through a tight regulation of survival and proliferation pathways.
\end{abstract}

Epicatechin: NF-кB signalling: Activator protein-1: Nuclear factor-erythroid 2p45-related factor-2

Epidemiological studies have related a diet rich in fruits and vegetables to the prevention of chronic degenerative diseases linked to oxidative stress ${ }^{(1)}$. Thus, the antioxidant activity of polyphenols has widely been involved in the explanation of their protective properties ${ }^{(2,3)}$. Additionally, these protective effects have been demonstrated to be mediated by mechanisms not only related to their antioxidant activity ${ }^{(4,5)}$.

Epicatechin is a flavonoid commonly found in the diet, particularly abundant in $\operatorname{cocoa}^{(6,7)}$. Numerous studies have demonstrated that epicatechin possesses in vitro antioxidant activity, can effectively scavenge free radicals ${ }^{(2,3)}$ and may play a role in modulating oxidative stress by preventing reactive oxygen species (ROS) generation ${ }^{(4,5,8)}$. Moreover, epicatechin exerts a cytoprotective role since it activates survival and proliferation pathways ${ }^{(4,5)}$. In this regard, it has been suggested that epicatechin might exert beneficial actions by stimulating the antioxidant defence response through the redox-regulated transcription factors and by modulating gene expression and signal cascades, such as mitogen-activated protein kinases $(\mathrm{MAPK})^{(4,9,10)}$. However, further studies to elucidate its molecular mechanism of action are needed.

A number of transcription factors have been connected to the oxidative stress, such as $\mathrm{NF}-\kappa \mathrm{B}$, activator protein-1 (AP-1) and nuclear factor erythroid 2p45-related factor-2 (Nrf2), which also modulate signalling pathways involved in the regulation of cell detoxification, proliferation, survival, death and differentiation ${ }^{(11,12)}$. NF- $\mathrm{B}$ is activated in the cytoplasm by disruption of the association of NF- $\kappa \mathrm{B}$ with inhibitor of $\kappa \mathrm{B}$ protein $(\mathrm{I} \kappa \mathrm{B})$. The phosphorylation of I $\mathrm{B}$ by the IкB kinase (IKK) complex results in the degradation of $\mathrm{I} \kappa \mathrm{B}$, leading to the nuclear translocation of NF- $\kappa \mathrm{B}$ where it can transactivate NF- $\mathrm{B}$ target genes involved in cell proliferation, anti-apoptosis, survival, etc ${ }^{(13)}$.

Abbreviations: AKT, protein kinase B; AP-1, activator protein-1; DPI, diphenyleneiodonium; ERK, extracellular regulated kinase; IкB, inhibitor of $к \mathrm{~B}$ protein; IKK, IкB kinase; MAPK, mitogen-activated protein kinase; Nrf2, nuclear transcription factor erythroid 2p45-related factor-2; PD98059, 2-(2-amino3-methoxyphenyl)-4H-1-benzopyran-4-one; PI3K, phosphatidylinositol-3-kinase; ROS, reactive oxygen species.

* Corresponding author: Dr Sonia Ramos, fax +34 9154936 27, email s.ramos@if.csic.es 
AP-1 is a transcription factor associated with cell proliferation, survival, differentiation, apoptosis and stress responses ${ }^{(12,14,15)}$. AP-1 is a dimer most commonly formed by the combination of structurally and functionally related members of the Jun protein family (c-Jun, JunB and JunD) and the Fos protein family (c-Fos, FosB, Fra-1 and Fra-2) ${ }^{(12,15,16)}$. AP-1 induction is modulated by different mechanisms, one of which is mediated by the MAPK cascade, such as $c$-jun amino-terminal kinase ${ }^{(14)}$. Once activated, $c$-jun amino-terminal kinase phosphorylates and activates c-Jun, which enhances the AP-1 transcriptional activity.

Nrf2 plays a central role in the induction of phase II detoxifying enzymes through its binding to the antioxidant response element. The primary control of Nrf2 function lies on its subcellular distribution rather than on the induction of the protein ${ }^{(11,17)}$. Nrf2 is sequestered in the cytoplasm as an inactive complex with its cytosolic repressor Kelch-like erythroid cellderived protein with $\mathrm{CNC}$ homology $(\mathrm{ECH})$-associated protein 1 (Keap-1). Dissociation of Nrf2 from Keap-1 is crucial for its nuclear translocation, followed by binding to the DNA and activation of cytoprotective genes ${ }^{(18)}$. In addition, different signal transduction pathways related to cell survival and proliferation (MAPK, phosphatidylinositol-3-kinase/protein kinase $\mathrm{B}$ (PI3K/AKT), protein kinase $\mathrm{C}$ ) might regulate $\mathrm{Nrf} 2^{(11,17)}$. Indeed, Nrf2 phosphorylation by different kinases at multiple sites seems to be an important mechanism in Nrf2-mediated antioxidant response element activation and in regulating the stability of this transcription factor ${ }^{(19,20)}$.

Redox-sensitive transcription factor $(\mathrm{NF}-\kappa \mathrm{B}, \mathrm{AP}-1$ and Nrf2) pathways are known to be important molecular targets in chemoprevention ${ }^{(21)}$. A cross-talk between upstream signalling pathways (MAPK, PI3K and protein kinase C) leading to differential modulation of these transcription factors appears to connect them, although evidence confirming a direct link among the transcription factors Nrf2, NF- $\mathrm{B}$ and AP-1 is lacking. Epicatechin seems not to affect AP-1 activity ${ }^{(22)}$, but stimulates Nrf2 nuclear translocation ${ }^{(23)}$ and inhibits NF-кB activity $^{(24)}$ in astrocytes and lymphoma cells, respectively, similarly to the epicatechin dimer, procyanidin $\mathrm{B} 2{ }^{(25)}$. On the other hand, this flavanol and its dimer can inhibit NF-кB activation induced by various agents ${ }^{(26,27)}$. However, comparable studies about the mechanisms underlying the chemopreventive effects of epicatechin alone related to transcription factors are limited. Most of these studies have been carried out after long-term treatments, but potential variations of the observed effects could take place in a time-dependent manner.

The present study analyses the influence of epicatechin, followed over time, on the mechanisms related to the regulation of major transcription factors (NF- $\mathrm{B}, \mathrm{AP}-1$ and Nrf2) in HepG2 cells. Results demonstrate that the survival effect of epicatechin is due to the early-initiated merged induction of critical redox-sensitive transcription factors linked to pro-survival pathways.

\section{Experimental methods}

\section{Materials and chemicals}

Epicatechin, 4',6-diamidino-2-phenylindole, diphenyleneiodonium (DPI), wortmannin, 2-(2-amino-3-methoxyphenyl)-4H1-benzopyran-4-one (PD98059), bovine serum albumin, gentamicin, penicillin $\mathrm{G}$ and streptomycin were purchased from Sigma Chemical (Madrid, Spain). Anti-NF- $\kappa$ B p65 (sc-7151 and sc-372), anti-IKK $\alpha$ (sc-7218 and sc-7607), anti-IкB $\alpha$ (sc-371), anti-phospho-Ser32-IкB $\alpha$ (sc-21869-R), anti c-Jun (sc-1694), anti-Nrf2 (C-20, sc-722), anti-Nrf2 (H-300, sc-13032), anti-poly(ADPribose)polymerase (antiPARP) (sc-7150) and anti-growth factor receptor-bound protein 2 (sc-255) were purchased from Santa Cruz Biotechnology Inc. (Santa Cruz, CA, USA). Alexa Fluor 594 goat anti-rabbit $\operatorname{IgG}(\mathrm{H}+\mathrm{L})(\mathrm{A} 11012)$ and anti- $\beta$-actin (4697) were obtained from Molecular Probes (Invitrogen, Merelbeke, Belgium) and Cell Signalling Technology (Izasa, Madrid, Spain), respectively. Reagents and consensus oligonucleotides for the electrophoretic mobility shift assays were from Promega (Madrid, Spain). Materials and chemicals for electrophoresis were from BioRad (Madrid, Spain). Cell-culture dishes and cell-culture medium were from Falcon (Cajal, Madrid, Spain) and Biowhitaker Europe (Lonza, Madrid, Spain), respectively. Vectashield was obtained from Vector Laboratories, Inc. (Burlingame, CA, USA).

\section{Cell culture, epicatechin treatment and obtaining of cell lysates}

Human hepatoma HepG2 cells were grown in Dulbecco's modified Eagle F-12 medium supplemented with $2.5 \%$ fetal bovine serum and antibiotics $(50 \mathrm{mg} / \mathrm{l}$; penicillin, streptomycin and gentamicin). Cells were kept at $37^{\circ} \mathrm{C}$ in a humidified atmosphere with $5 \% \mathrm{CO}_{2}$

To study the time-course effects of epicatechin, cells were grown in serum-free Dulbecco's modified Eagle F12 medium for $24 \mathrm{~h}$ before the assay, because the growth factors contained in the fetal bovine serum might influence the results. Subsequently, cells were treated with $10 \mu \mathrm{M}$-epicatechin and harvested at different incubation times $(0,5,10,15,30,60$, 120,240 and $1080 \mathrm{~min}$ ).

In the experiments with epicatechin and the ROS scavenger, DPI, cells were pre-incubated with DPI $(20 \mu \mathrm{M})$ for $30 \mathrm{~min}$ before $10 \mu \mathrm{M}$-epicatechin treatment during 240 or $1080 \mathrm{~min}$. Similarly, when cells were treated with epicatechin and the inhibitors wortmannin $(200 \mathrm{nM})$ or PD98059 $(50 \mu \mathrm{M})$, cells were pre-incubated for $2 \mathrm{~h}$ with the inhibitor before flavanol $(10 \mu \mathrm{M})$ treatment for 240 or $1080 \mathrm{~min}$.

To obtain the total cell lysates and detect I $\mathrm{KB}$ and phosphorylated $\mathrm{I} \kappa \mathrm{B}$, cells were harvested after different incubation times with epicatechin and centrifuged at $300 \mathrm{~g}$, $4^{\circ} \mathrm{C}$ for $5 \mathrm{~min}$. Cells were lysed in cold buffer composed of $25 \mathrm{mM}$-HEPES (pH 7.5), 0.3 M-NaCl, $1.5 \mathrm{mM}-\mathrm{MgCl}_{2}, 0.2 \mathrm{~mm}-$ EDTA, $0.5 \mathrm{~mm}$-dithiothreitol, $0.1 \%$ Triton X-100, $200 \mathrm{~mm}-$ $\beta$-glycerolphosphate, $0 \cdot 1 \mathrm{~mm}-\mathrm{Na}_{3} \mathrm{VO}_{4}, 2 \mu \mathrm{g} / \mathrm{ml}$ leupeptin and $1 \mathrm{mM}$-phenylmethylsulfonyl fluoride ${ }^{(28)}$. Lysates were centrifuged at $10000 \mathrm{~g}, 4^{\circ} \mathrm{C}$ for $10 \mathrm{~min}$. The supernatant fractions were collected to determine protein concentration by the Bio-Rad (Madrid, Spain) protein assay kit, and total cell lysates were sampled and stored at $-80^{\circ} \mathrm{C}$ until use for Western blotting analysis.

To obtain the nuclear and cytosolic cell lysates and detect $\mathrm{NF}-\kappa \mathrm{B}, \mathrm{IKK}, \mathrm{c}-\mathrm{Jun}$ and Nrf2, cells were incubated with cold lysis buffer A, containing $10 \mathrm{mM}-\mathrm{HEPES}$ ( $\mathrm{pH} 7.9$ ), $1.5 \mathrm{mM}-$ $\mathrm{MgCl}_{2}, 10 \mathrm{mM}-\mathrm{KCl}, 0.5 \mathrm{mM}$-dithiothreitol and $0.2 \mathrm{~mm}$-phenylmethylsulfonyl fluoride for $10 \mathrm{~min}$. Next, samples were 
centrifuged at $10000 \mathrm{~g}, 4^{\circ} \mathrm{C}$ for $10 \mathrm{~min}$ and the supernatant fractions (cytosolic cell extracts) were collected to determine protein concentration. Pellets were re-suspended in cold lysis buffer B, composed of 20 mM-HEPES (pH 7.9), $25 \%$ glycerol, $420 \mathrm{~mm}-\mathrm{NaCl}, 1.5 \mathrm{~mm}-\mathrm{MgCl}_{2}, 0.2 \mathrm{~mm}$-EDTA, $0.5 \mathrm{~mm}$ dithiothreitol, $2.5 \mu \mathrm{g} / \mathrm{ml}$ leupeptin, $0.2 \mathrm{~mm}$-phenylmethylsulfonyl fluoride and $2.5 \mu \mathrm{g} / \mathrm{ml}$ aprotinin, and kept for $20 \mathrm{~min}$ on ice. Samples were centrifuged at $14000 \mathrm{~g}, 4^{\circ} \mathrm{C}$ for $10 \mathrm{~min}$ and the supernatant fractions (nuclear cell extracts) were collected to analyse protein concentration. Both cell extracts were stored at $-80^{\circ} \mathrm{C}$ until use for Western blotting or electrophoretic mobility shift assay.

\section{Protein analysis by Western blotting}

Equal amounts of protein $(100 \mu \mathrm{g})$ were separated by SDSPAGE. Proteins were transferred to polyvinylidene difluoride filters (Protein Sequencing Membrane; Millipore, Madrid, Spain). Membranes were incubated with the corresponding primary antibody and then with peroxide-conjugated antirabbit Ig as the secondary antibody (GE Healthcare, Madrid, Spain). Blots were developed with the ECL Western blotting detection reagents (GE Healthcare, Madrid, Spain). Antigrowth factor receptor-bound protein-2 and anti-poly(ADPribose)polymerase (anti-PARP) antibodies were used as markers for the cytosolic and nuclear extracts, respectively. Equal loading of Western blot was ensured by $\beta$-actin and band quantification was carried out with a scanner and the Scion Image software (Scion Corp., Frederick, MD, USA).

\section{Electrophoretic mobility shift assay}

Equal amounts of protein $(5-10 \mu \mathrm{g})$ were incubated for $20 \mathrm{~min}$ at room temperature with NF- $\kappa$ B or AP- $1-\alpha-{ }^{32} \mathrm{P}-$ labelled consensus oligonucleotides in binding buffer, as previously described $^{(29)}$. Labelling was performed by using T4 polynucleotide kinase and $\alpha-{ }^{32} \mathrm{P}$-labelled deoxyadenosine triphosphate, being NF- $\kappa$ B and AP-1 consensus oligonucleotides: 5'-AGTTGAGGGGACTTTCCCAGGC- $3^{\prime}$ and $5^{\prime}$-CGCTTGATGAGTCAGCCGGAA- $3^{\prime}$, respectively. The binding reaction mixture contained $0.5 \mathrm{ng}$ of doubled-stranded oligonucleotide probe, $1 \mu \mathrm{g}$ of poly $(\mathrm{dI}-\mathrm{dC})$ and nuclear extracts in $2 \mu \mathrm{l}$ incubation buffer (50 mM-2-amino-2-hydroxymethyl-propane-1,3-diol (Tris) $-\mathrm{HCl}(\mathrm{pH} 7 \cdot 5), 250 \mathrm{~mm}-\mathrm{NaCl}, 5 \mathrm{mM}-\mathrm{MgCl}_{2}, 2.5 \mathrm{~mm}-$ EDTA, $2.5 \mathrm{~mm}$-dithiothreitol and $20 \%$ glycerol). Samples were loaded on a $6 \%$ polyacrylamide gel and were separated via electrophoresis at $150 \mathrm{mV}$ in $0.53 \mathrm{~mm}$-Tris-borate-EDTA running buffer for $2-3 \mathrm{~h}$, at room temperature. Then, the gel was autoradiographed and the complexes quantified by using a scanner and accompanying software.

\section{Immunofluorescence microscopy}

Immunofluorescence assays were performed as previously described ${ }^{(30,31)}$. Briefly, HepG2 cells were seeded $(25000$ cells/well) on glass coverslips with Dulbecco's modified Eagle F-12 medium supplemented with fetal bovine serum for $24 \mathrm{~h}$ and changed to serum-free medium $24 \mathrm{~h}$ before the assay. After incubation with epicatechin for the indicated times, cells were washed with PBS at room temperature and then fixed with $3.7 \%$ paraformaldehyde for $10 \mathrm{~min}$ at room temperature. Cells were rinsed with PBS, permeabilised with ice-cold acetone and subsequently blocked with $1 \%$ bovine serum albumin. Cells were incubated with the corresponding primary antibody, as indicated in the legends of Figs. 2 and 6, and then incubated with the anti-rabbit Alexa Fluor594 conjugated secondary antibody. Nuclei were visualised by using 6-diamidino-2-phenylindole staining. The coverslips were mounted in Vectashield and images were taken with a Zeiss Axiovert 200M immunofluorescence microscope (Carl Zeiss Microimaging $\mathrm{GmbH}$, Munich, Germany) at $63 \times$ magnification. AxioVisionRel 4.6 software was used for the analysis of the images obtained.

\section{Statistics}

Before statistical analysis, data were tested for homogeneity of variances by the test of Levene; for multiple comparisons, one-way ANOVA was followed by the Bonferroni test when variances were homogeneous or by the Tamhane test when variances were not homogeneous. $P<0.05$ was considered significant. SPSS (version 15.0; SPSS, Inc., Chicago, IL, USA) was used.

\section{Results}

Time-course effects on $N F-\kappa B$ pathway

$N F-\kappa B$ regulation. To study the time-course effect of epicatechin on NF- $\mathrm{BB}$ in HepG2 cells, cytosolic and nuclear $\mathrm{NF}-\kappa \mathrm{B}(\mathrm{p} 65)$ levels were analysed. As shown in Fig. 1(A) and $(\mathrm{B})$, epicatechin increased the nuclear translocation of NF- $\kappa \mathrm{B}$ after $5 \mathrm{~min}$ of treatment and remained enhanced up to $240 \mathrm{~min}$, observed by the remarkable augmentation in the relative amount of nuclear $v$. cytosolic NF- $\kappa \mathrm{B}$ levels. The nuclear:cytosolic NF- $\mathrm{B}$ ratio returned to control levels at $1080 \mathrm{~min}$ (Fig. 1(A) and (B)).

Phosphorylation and degradation of inhibitor of $\kappa B \alpha$ protein. To further investigate the regulation of upstream components of the NF- $\kappa \mathrm{B}$ signalling pathway, ІкB $\alpha$ modulation was studied. Epicatechin induced the phosphorylation of $\mathrm{I} \kappa \mathrm{B} \alpha$ after a short incubation time $(5 \mathrm{~min})$, which was maintained up to $10 \mathrm{~min}$ and then slowly decreasing to control levels (15-1080 min) (Fig. 2(A) and (B)).

I $\kappa \mathrm{B} \alpha$ degradation was observed after $5 \mathrm{~min}$ of treatment with epicatechin and remained diminished until $240 \mathrm{~min}$ (Fig. 2(A) and (C)). Additionally, fluorescence microscopy showed the cytosolic localisation of IкB $\alpha$ as well as its degradation (Fig. 2(D)). In this analysis, IкB $\alpha$ levels were clearly decreased up to $240 \mathrm{~min}$, returning to control levels at $1080 \mathrm{~min}$ of incubation (Fig. 2(D)).

Regulation of the I $\mathrm{B}$ kinase complex. IKK is a complex composed of two catalytic subunits (IKK $\alpha$ and IKK $\beta$ ) and a regulatory subunit (NF- $\mathrm{B}$ essential modifier (NEMO)/ IKK $\gamma$ ), which are upstream kinases of $\mathrm{I} \kappa \mathrm{B} \alpha^{(32)}$. Recent studies have provided evidence that IKK subunits also translocate into the nucleus to regulate $N F-\kappa B-d e p e n d e n t$ and -independent gene expression ${ }^{(32)}$. To gain more insight into the NF- $\kappa \mathrm{B}$ pathway regulation, cytosolic and nuclear levels of both catalytic subunits of IKK $(\mathrm{IKK} \alpha / \beta)$ were analysed. Western blot analysis demonstrated that cytosolic IKK $\alpha$ levels were increased after $5 \mathrm{~min}$ of treatment, and remained enhanced up to $2 \mathrm{~h}$, showing lower levels than controls after $18 \mathrm{~h}$ of incubation (Fig. 3(A) and (B)). An opposite effect 
(A)

NF-кB (cyt)

GRB2

NF-kB (nuc)

PARP
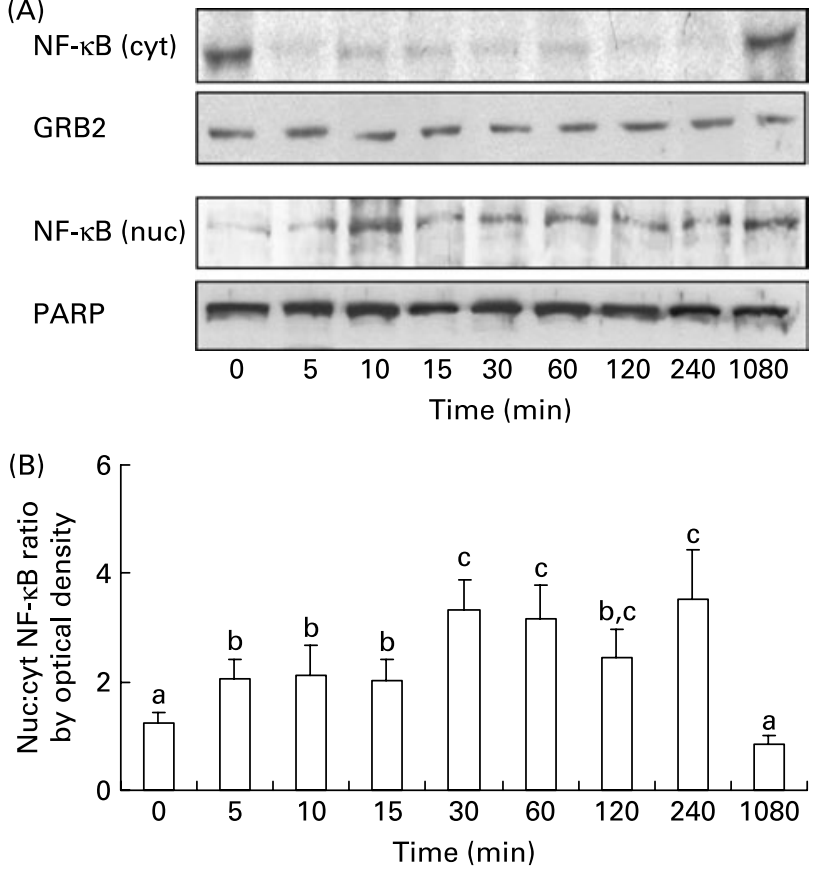

Fig. 1. Time-dependent effect of epicatechin on modulation of NF-kB(p65) cytosolic (cyt) and nuclear (nuc) levels. (A) Bands of representative experiments. Anti-growth factor receptor-bound protein-2 (GRB2) and anti-poly (ADPribose)polymerase (anti-PARP) antibodies were used as markers for the cyt and nuc extracts, respectively. (B) Nuc:cyt NF-кB ratio of bands determined by densitometric quantification. Values are means $(n 6)$, with standard deviations represented by vertical bars. ${ }^{\mathrm{a}, \mathrm{b}, \mathrm{c}}$ Mean values with unlike letters were significantly different $(P<0.05)$.

was observed on the cytosolic IKK $\beta$ levels, which clearly decreased after $5 \mathrm{~min}$ up to $240 \mathrm{~min}$, returning to control values after $1080 \mathrm{~min}$ of treatment (Fig. 3(A) and (B)).

In the nucleus, after a prior enhancement of the IKK $\alpha$ levels at 5-10 min of incubation, epicatechin induced a decrease at $15 \mathrm{~min}$, which was maintained up to $1080 \mathrm{~min}$ (Fig. 3(A) and (C)). Parallel to this, epicatechin evoked an increase in the nuclear IKK $\beta$ levels, which remained enhanced up to $60 \mathrm{~min}$ to return to control levels from $120 \mathrm{~min}$ of treatment onwards (Fig. 3(A) and (C)).

\section{Time-course effects on $N F-\kappa B$ activity}

To further investigate the time-course effect of epicatechin

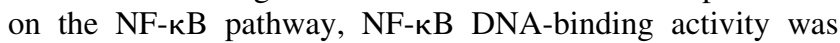
studied. Epicatechin induced an early increase of NF-кB activity ( $5 \mathrm{~min}$ ), which remained enhanced up to $240 \mathrm{~min}$ and reached control values at the longest incubation time (1080 min) (Fig. 4).

\section{Time-course modulation of activator protein-1 and c-Jun}

To study the time-dependent epicatechin effect on AP-1 DNA-binding activity, as well as on cytosolic and nuclear c-Jun levels, both parameters were assayed for the indicatedtimes.

Activator protein-1 DNA-binding activity. Epicatechin induced an early increase of the AP-1 DNA-binding activity (5 min), which remained higher than controls up to 1080 min (Fig. 5).
(A)
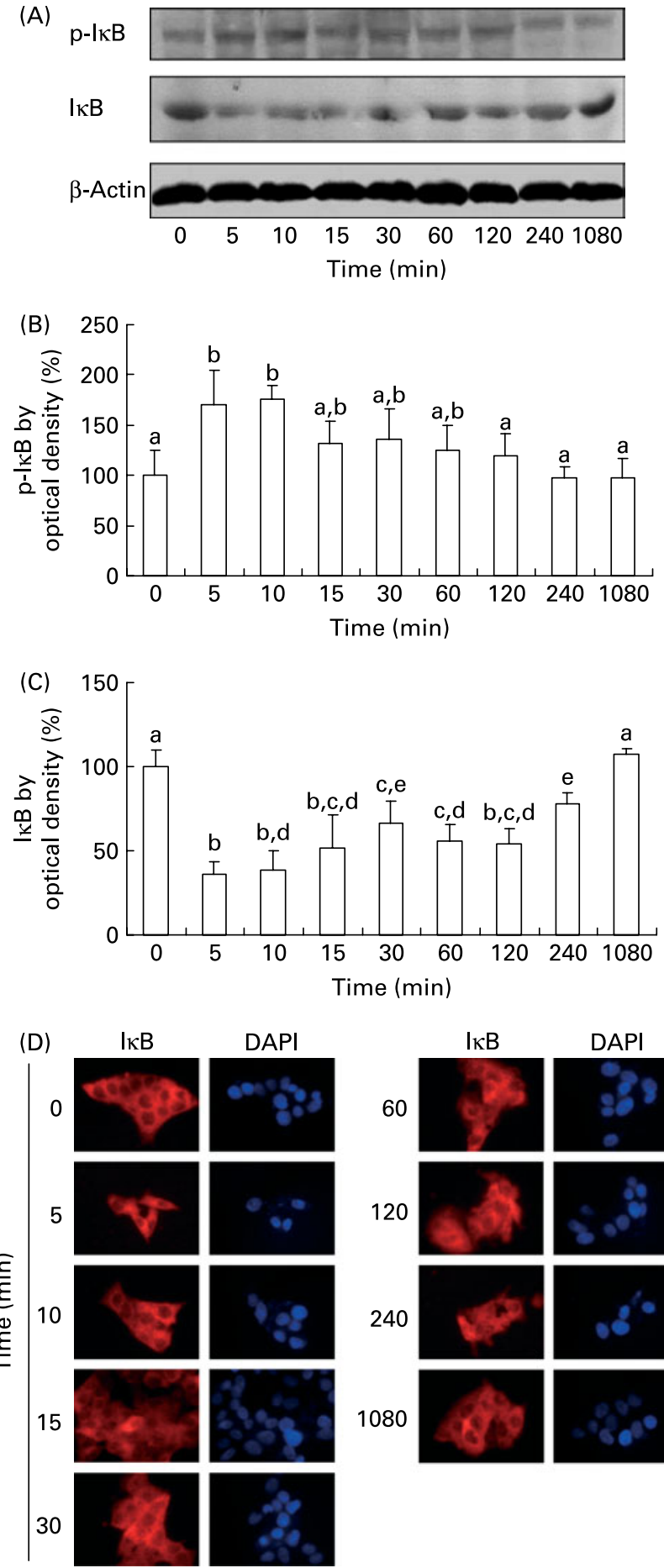

DAPI

Fig. 2. Time-dependent effect of epicatechin on phosphorylated inhibitor of $\kappa B$ protein $\left(p-I_{\kappa} B\right)-\alpha$ (Ser32) and total $I_{\kappa} B \alpha$ levels. (A) Representative blots. Normalisation of Western blots, either $p-I_{\kappa} B \alpha$ or total $I_{\kappa} B \alpha$ levels, was ensured by $\beta$-actin. (B) Percentage values of $p-I_{\kappa} B \alpha$ levels relative to the control condition, determined by densitometric quantification. Values are means ( $n$ 6), with standard deviations represented by vertical bars. ${ }^{a, b}$ Mean values with unlike letters were significantly different $(P<0.05)$. (C) Percentage values of total $I_{\kappa} B \alpha$ levels relative to the control, determined by densitometric quantification. Values are means $(n$ 6), with standard deviations represented by vertical bars. ${ }^{a-e}$ Mean values with unlike letters were significantly different $(P<0.05)$. (D) Immunofluorescence images of timedependent status and cellular localisation of $1 \kappa \mathrm{B} \alpha$ (red signal). 6-Diamidino2-phenylindole (DAPI) staining was used to visualise nuclei (blue signal). These results are representative of two independent experiments. 

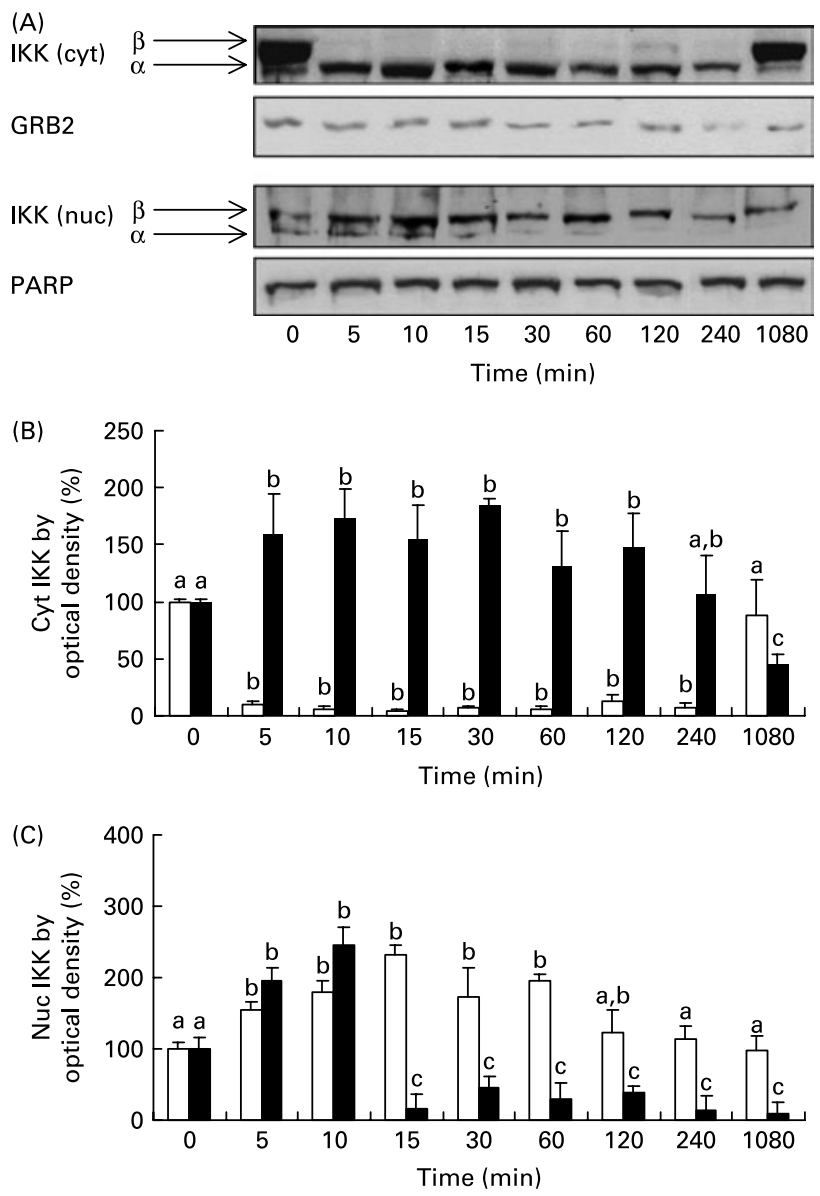

Fig. 3. Time-course effect of epicatechin on cytosolic (cyt) and nuclear (nuc) I $\mathrm{B}$ kinase (IKK) $\alpha$ and IKK $\beta$ levels. (A) Representative blots. Anti-growth factor receptor-bound protein-2 (anti-GRB2) and anti-poly(ADPribose)polymerase (anti-PARP) antibodies were used as markers for the cyt and nuc extracts, respectively. (B) Percentage values of cyt levels of IKK $\alpha(\boldsymbol{\square})$ and $\operatorname{IKK} \beta(\square)$ relative to the control conditions, determined by densitometric quantification. Values are means $(n 6)$, with standard deviations represented by vertical bars. ${ }^{\mathrm{a}, \mathrm{b}, \mathrm{c}}$ Mean values (for IKK $\alpha$ or IKK $\beta$ ) with unlike letters were significantly different $(P<0 \cdot 05)$. (C) Percentage values of nuc levels of IKK $\alpha$ $(\square)$ and IKK $\beta$ ( $\square$ ) relative to the control conditions, determined by densitometric quantification. Values are means $(n 6)$, with standard deviations represented by vertical bars. ${ }^{a, b, c}$ Mean values (for IKK $\alpha$ or IKK $\beta$ ) with unlike letters were significantly different $(P<0.05)$.

Subcellular levels and localisation of c-Jun. As shown in Fig. 6, c-Jun protein was mainly located in the nucleus of HepG2 cells. In agreement with the previous results of AP-1 activity, epicatechin induced an early enhancement of the nuclear c-Jun protein levels ( $5 \mathrm{~min})$, which was sustained up to the longest incubation time (1080 min) (Fig. 6(A)). The nuclear localisation of the protein was also shown by the immunofluorescence analysis (Fig. 6(B)).

\section{Time-course nuclear transcription factor erythroid 2p45-related factor-2 modulation}

To assess the implication of Nrf2 on epicatechin effects, time-course studies on the nuclear and cytosolic levels of this transcription factor were performed. No phosphorylated Nrf2 $(100 \mathrm{kDa})$ was detected in the cytosolic fractions of HepG2 cells. Epicatechin concurrently increased nuclear translocation of $\mathrm{Nrf} 2(57 \mathrm{kDa})$ and nuclear content of phosphorylated Nrf2 $(100 \mathrm{kDa})$ after $15 \mathrm{~min}$ of treatment (Fig. 7(A)-(C)). This effect remained for up to $240 \mathrm{~min}$ as can be deduced from the increment in the nuclear content and nuclear:cytosolic ratio of Nrf2 (Fig. 7(A)-(C)). Control levels were attained at $1080 \mathrm{~min}$ of incubation.

\section{Epicatechin-induced nuclear transcription factor erythroid} $2 p 45$-related factor- 2 and $N F-\kappa B$ expressions are mediated by reactive oxygen species, phosphatidylinositol-3-kinase and extracellular regulated kinase $1 / 2$

Nrf2 and NF-кB have also been related to ROS and survival and proliferation pathways ${ }^{(11,13,17)}$. Since an epicatechindependent ROS attenuation and AKT and ERK activation have been reported ${ }^{(4,5)}$, the possible implication of these factors on the regulation of $\mathrm{NF}-\kappa \mathrm{B}$ and $\mathrm{Nrf} 2$ expressions was analysed after 4 and $18 \mathrm{~h}$ of incubation. As shown in Fig. 8(A)-(D), DPI prevented the phosphorylation and nuclear translocation of Nrf2 induced by the flavanol at $4 \mathrm{~h}$, which were also diminished below control levels at the longest incubation time $(18 \mathrm{~h})$, as shown by the remarkable decrease in the nuclear phosphorylated content and nuclear:cytosolic ratio. Both the nuclear:cytosolic ratio and nuclear phosphorylated Nrf2 levels (100 and $57 \mathrm{kDa}$, respectively) remained unaltered after treating control cells with DPI at 4 and $18 \mathrm{~h}$. On the other
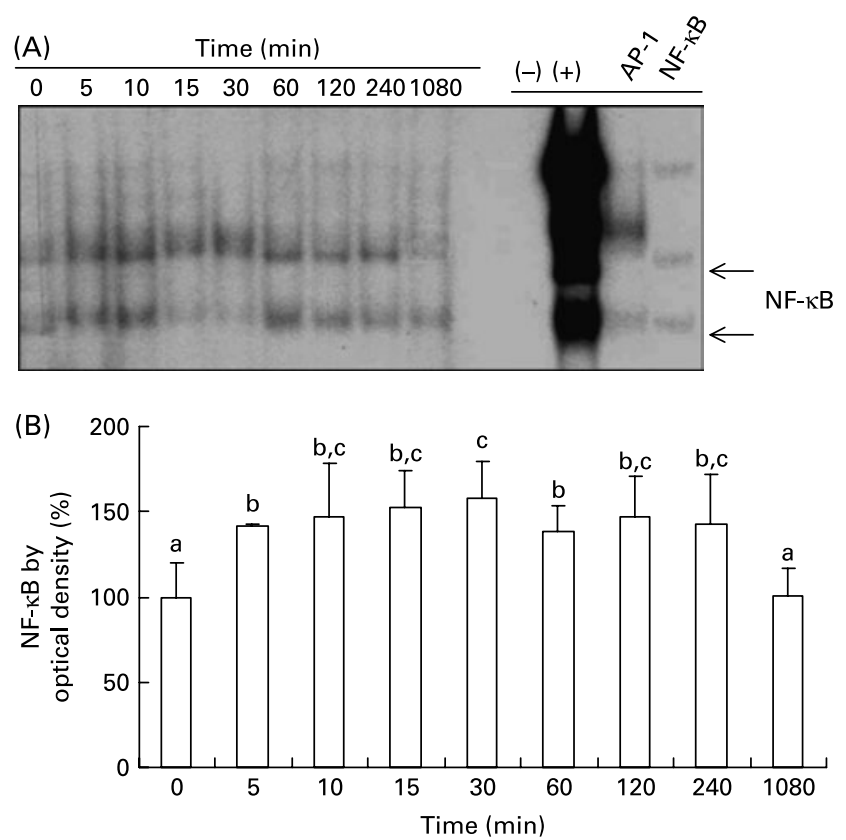

Fig. 4. Time-course effect of epicatechin on NF-кB activity. (A) Representative autoradiography of NF- $\mathrm{B}$ electrophoretic mobility shift assay (EMSA). $(\leftarrow)$, Positions of specific NF-кB-DNA complexes. Negative controls $(-)$ without nuclear extract and positive controls $(+)$ with a pure HeLa nuclear extract were included in each experiment. To determine the specificity of the NF-кB-DNA complexes, a nuclear fraction was incubated in the presence of 100 -fold excess of unlabelled oligonucleotide containing the consensus sequence for either an unspecific competitor (activator protein-1; AP-1) or specific competitor (NF- $\kappa \mathrm{B}$ ) before the binding assay. (B) NF- $\mathrm{B}$ activity as a percentage relative to the control condition, determined by densitometric quantification. Values are means $(n 6)$, with standard deviations represented by vertical bars. ${ }^{\mathrm{a}, \mathrm{b}, \mathrm{c}}$ Mean values with unlike letters were significantly different $(P<0.05)$. 

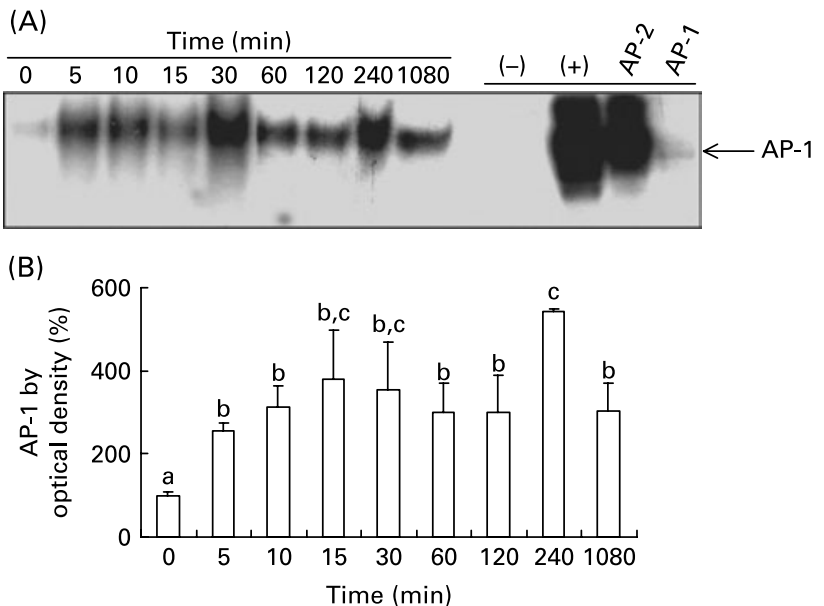

Fig. 5. Time-course-dependent effect of epicatechin on activator protein-1 (AP-1) activity. (A) Representative autoradiography of AP-1 electrophoretic mobility shift assay (EMSA). ( $\leftarrow)$, Positions of specific AP-1-DNA complexes. Negative controls $(-)$ without nuclear extract and positive controls $(+)$ with a pure HeLa nuclear extract were included in each experiment. To determine the specificity of the AP-1-DNA complexes, a nuclear fraction was incubated in the presence of 100-fold excess of unlabelled oligonucleotide containing the consensus sequence for either an unspecific competitor (activator protein-2; AP-2) or specific competitor (AP-1) before the binding assay. (B) AP-1 activity as a percentage relative to the control condition, determined by densitometric quantification. Values are means $(n 7)$, with standard deviations represented by vertical bars. ${ }^{a, b, c}$ Mean values with unlike letters were significantly different $(P<0.05)$

hand, DPI treatment also decreased the epicatechin-induced NF- $\kappa$ B levels at both tested times (Fig. 8(E) and (F)), resulting in the inhibition of NF- $\mathrm{B}(\mathrm{p} 65)$ nuclear translocation. DPI alone provoked an inhibition of the NF- $\kappa \mathrm{B}$ translocation at $18 \mathrm{~h}$, although levels similar to controls were observed after $4 \mathrm{~h}$ of incubation.

Treatment of HepG2 cells with wortmannin, an inhibitor of AKT, followed by addition of epicatechin $(10 \mu \mathrm{M})$, diminished the Nrf2-induced activation (57 and $100 \mathrm{kDa}$ Nrf2 levels), returning to control levels at $4 \mathrm{~h}$. After $18 \mathrm{~h}$ of incubation, the nuclear phosphorylated content and nuclear:cytosolic ratio of $\mathrm{Nrf} 2(100$ and $57 \mathrm{kDa})$ decreased below control levels (Fig. 9(A)-(D)). NF-кB nuclear translocation was unaltered after treating the cells with epicatechin and wortmannin at both times (4 and 18h) (Fig. 9(E) and (F)). In addition, wortmannin alone inhibited phosphorylation and nuclear translocation of Nrf2 and did not alter the nuclear:cytosolic ratio of NF- $\mathrm{KB}$ at both incubation times (Fig. 9).

Inhibition of epicatechin-induced ERK activation by the ERK selective inhibitor PD98059 after 240 min of incubation led to nuclear phosphorylated levels and a nuclear:cytosolic ratio of Nrf2 (100 and $57 \mathrm{kDa}$ ) comparable with those of controls at $4 \mathrm{~h}$ of treatment (Fig. 10(A)-(D)). Similarly, a decrease in Nrf2 phosphorylation and nuclear translocation was observed at $18 \mathrm{~h}$ in epicatechin + PD98059-treated cells (Fig. 10(A)-(D)). In addition, Nrf2 phosphorylation and translocation were inhibited by PD98059 incubation at $1080 \mathrm{~min}$ in control cells (Fig. 10(A)-(D)). Selective blockage of ERK by PD98059 resulted in the inhibition of NF- $\kappa$ B translocation after 4 and $18 \mathrm{~h}$ of incubation with epicatechin and PD98059 (Fig. 10(E) and (F)). Moreover, PD98059 alone did not alter the subcellular localisation of NF- $\kappa$ B after 4 and $18 \mathrm{~h}$ of incubation (Fig. 10(E) and (F)).

\section{Discussion}

Polyphenols have been shown to possess anti-inflammatory, anti-thrombogenic, antioxidant and anticarcinogenic activities $^{(1,9,33)}$. Recently, much interest has been focused on analysing these biological properties, as polyphenolic compounds seem to act on cellular oxidative stress, antioxidant metabolism, cell-cycle regulation, induction and/or suppression of apoptosis and cell signalling ${ }^{(9,10)}$. Since NF-кB, AP-1 and Nrf2 play a central role in the cell antioxidant defence, survival and proliferation, these transcription factors were investigated as epicatechin targets. We have reported that epicatechin $(10 \mu \mathrm{M})$ induces an enhancement of the intrinsic cellular tolerance against oxidative insults, a transient attenuation of intracellular ROS levels and a sustained activation of major survival and proliferation signalling proteins (AKT, ERK, etc), in concert with an early inactivation of key death-related signals ${ }^{(4,5)}$. In the present study, we show that epicatechin transiently activates the NF- $\mathrm{B}$ cascade and Nrf2 signalling by stimulating PI3K/AKT and ERK pathways and induces a sustained enhancement of AP-1-binding-activity by up-regulating the nuclear levels of c-Jun.

It is noteworthy to mention that the concentration of $10 \mu \mathrm{M}$ epicatechin used in the study is not far from realistic. In human subjects, levels of $0 \cdot 2-0 \cdot 4 \mu \mathrm{M}$-epicatechin have been

(A)

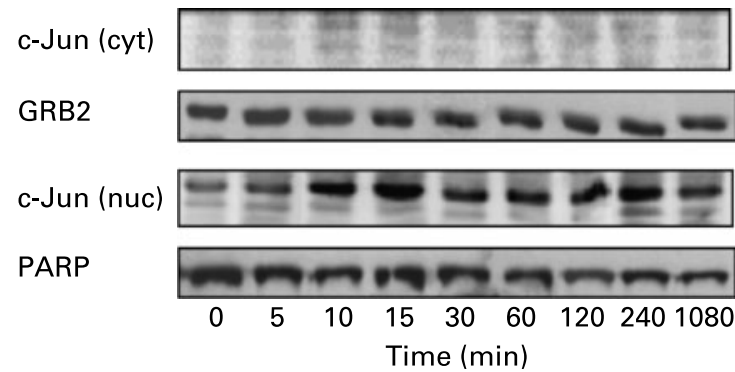

(B) c-Jun

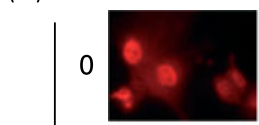
DAPI
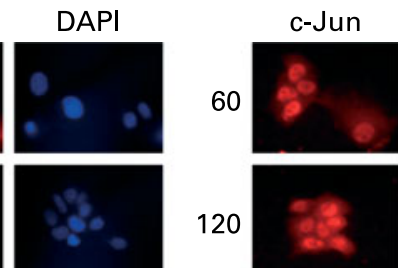
DAPI

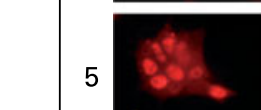

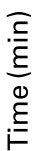

10
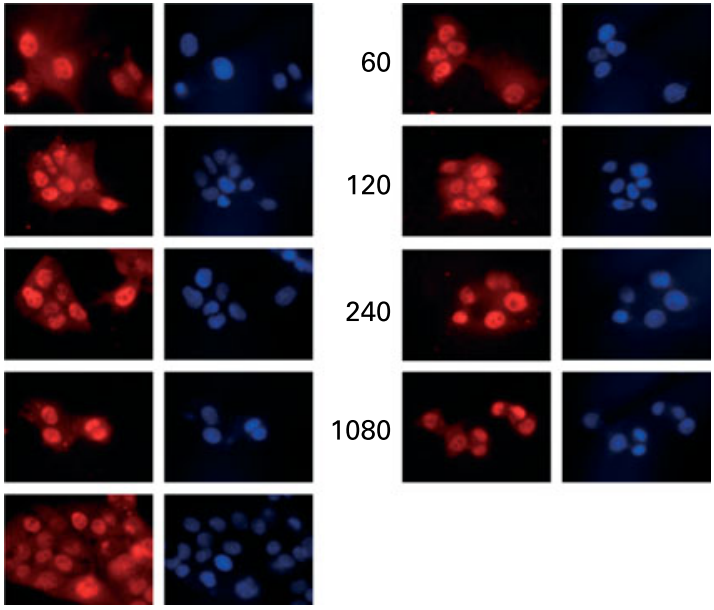

10
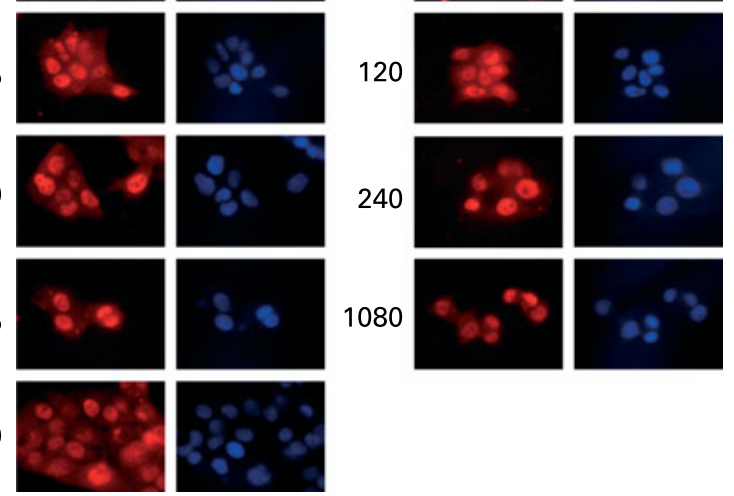

Fig. 6. Time-dependent effect of epicatechin on cytosolic (cyt) and nuclear (nuc) levels and subcellular localisation of c-Jun. (A) Representative bands (n 3). Anti-growth factor receptor-bound protein-2 (anti-GRB2) and anti-poly (ADPribose)polymerase (anti-PARP) antibodies were used as markers for the cyt and nuc extracts, respectively. (B) Immunofluorescence images of the subcellular localisation of c-Jun (red signal). 6-Diamidino-2-phenylindole (DAPI) staining was used to visualise nuclei (blue signal). These results are representative of two independent experiments. 
(A) Nrf2 (cyt, 57 kDa)

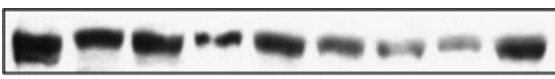

GRB2

Nrf2 (nuc, $100 \mathrm{kDa}$ )

Nrf2 (nuc, $57 \mathrm{kDa}$ )

PARP

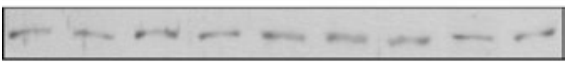

Fig. 7. Time-course effect of epicatechin on cytosolic (cyt) and nuclear (nuc) nuclear transcription factor erythroid 2p45-related factor-2 (Nrf2) levels (100 and $57 \mathrm{kDa}$ ). (A) Bands of representative experiments. Anti-growth factor receptor-bound protein-2 (anti-GRB2) and anti-poly(ADPribose)polymerase (anti-PARP) antibodies were used as markers for the cyt and nuc extracts, respectively. (B) Percentage values of nuc levels of phosphorylated Nrf2 $(100 \mathrm{kDa})$ relative to the control condition, determined by densitometric quantification. Values are means $(n 6)$, with standard deviations represented by vertical bars. ${ }^{a, b}$ Mean values with unlike letters were significantly different $(P<0.05)$. (C) Nuc:cyt Nrf2 $(57 \mathrm{kDa})$ ratio of bands, determined by densitometric quantification. Values are means (n 6), with standard deviations represented by vertical bars. ${ }^{a, b}$ Mean values with unlike letters were significantly different $(P<0.05)$.

observed after ingestion of $50 \mathrm{~g}^{(34)}$ and $80 \mathrm{~g}^{(35)}$ chocolate and $426 \mathrm{ml}$ green tea containing $76.5 \mathrm{mg}$ epicatechin ${ }^{(36)}$. Moreover, rats fed with epicatechin showed plasma concentrations of epicatechin and epicatechin metabolites of about $35 \mu \mathrm{M}$ at $1 \mathrm{~h}$ after oral administration of $172 \mu \mathrm{mol}$ epicatechin $/ \mathrm{kg}$ body weight ${ }^{(37)}$. However, at present the potential contribution of the epicatechin metabolites to the biological activity is unclear and it should not be underestimated ${ }^{(38,39)}$; its evaluation will require further studies. In this regard, a more accurate approach recently used is the incubation of cultured cells with plasma obtained from volunteers consuming the molecule or food of interest ${ }^{(40)}$.
Activation of the NF-кB signalling pathway by epicatechin appeared to be mediated by an early increase of the NF$\kappa \mathrm{B}(\mathrm{p} 65)$ nuclear translocation, which was accompanied by transiently increased phosphorylated IкB $\alpha$ levels and subsequent proteolytic degradation of $І \kappa \mathrm{B}$, consistent with the increased NF- $\mathrm{B}$-binding activity. Later, phosphorylation of I $\mathrm{B} \alpha$ was returned to control levels by the epicatechin treatment, suggesting that the stimulating effects of this polyphenol occur upstream of $\mathrm{I} \kappa \mathrm{B} \alpha^{(13)}$. In this regard, it has been reported that IKK $\beta$ plays a main role in NF- $\mathrm{BB}$ activation and that its absence causes death due to extensive liver damage from apoptosis $^{(32)}$, while IKK $\alpha$ is crucial for a correct development as well as for cell proliferation and differentiation ${ }^{(32)}$. Moreover, recent studies have demonstrated that IKK subunits can translocate into the nucleus where IKK $\alpha$, among other activities, mediates $\mathrm{NF}-\kappa \mathrm{B}$ transcription and cell proliferation $^{(32,41)}$, although the nuclear accumulation of this protein has been related to the promotion of apoptosis through a novel molecular mechanism ${ }^{(42)}$. Nuclear IKK $\beta$ would recruit to NF- $\kappa \mathrm{B}$-dependent promoters, such as $\mathrm{I}_{\kappa} \mathrm{B}^{(32,43)}$. Therefore, early epicatechin-induced IKK $\alpha$ and IKK $\beta$ nuclear translocation could be correlated to the enhanced NF- $\kappa B$-binding activity by $\mathrm{IKK} \alpha$ and to $\mathrm{I} \kappa \mathrm{B}$ phosphorylation by IKK $\beta$. In addition, several studies have also reported that IKK $\beta$ phosphorylates multiple $\mathrm{NF}-\kappa \mathrm{B}(\mathrm{p} 65)$ sites, suggesting that this catalytic subunit is not only involved in the pathway leading

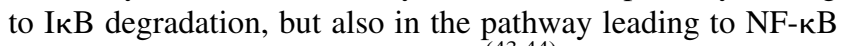
phosphorylation and transactivation ${ }^{(43,44)}$. All this is in agreement with previously reported stimulatory effects of IKK induced by other flavonoids in Chang liver cells ${ }^{(45)}$. However, in different cell types, under NF- $\kappa \mathrm{B}$-stimulated conditions other authors have reported inhibitory effects evoked by epicatechin, such as decreased NF- $\mathrm{KB}(\mathrm{p} 65)$ levels and IKK phosphorylation, inhibition of both NF- $\mathrm{BB}$ nuclear translocation and NF- $\mathrm{kB}$-binding activity, as well as inhibition of the induction of IкB phosphorylation and degradation ${ }^{(24,26,27,46)}$

Numerous reports have demonstrated that AP-1, in addition to its pro-apoptotic function, is also critically involved in cell survival, proliferation, transformation and differentiation ${ }^{(15)}$. An extended explanation for these functions is that a robust and persistent activation of AP-1 in DNA-damaged cells may trigger apoptosis, but the activation of AP-1 in capable proliferative cells promotes proliferation and survival ${ }^{(14,15)}$. In this regard, recent studies have demonstrated that the activation of the AP-1 signalling pathway controls cell proliferation through cell-cycle regulation in hepatocytes and other cell types ${ }^{(15)}$. Opposite to the activation of AP-1 described in the present paper, several studies have reported that epicatechin alone is unable to modify AP-1 activity even in the presence of AP-1 stimulators $^{(22,47)}$, although at higher concentrations $(100 \mu \mathrm{M})$ epicatechin induces an inhibitory effect on AP-1 activity together with a slightly decreased cell viability ${ }^{(22)}$. The divergence for AP-1 activity modulation could be related to the specific modulation of transcription factors for the different cell types ${ }^{(48,49)}$ and to the different concentrations of the flavanol used.

Expression of AP-1 genes is regulated by the phosphorylation and the expression of individual AP-1 components (Jun and Fos). Jun expression is required for fetal hepatocyte survival, whereas in differentiated hepatocytes it is essential for cellcycle progression $^{(15)}$. Moreover, Jun and NF- $\kappa B$ can collaborate 
(A)

$$
\begin{array}{r}
240 \min \mid \operatorname{Nrf2}(\text { nuc, } 100 \mathrm{kDa}) \\
1080 \min \mid \operatorname{Nrf2}(\text { nuc, } 100 \mathrm{kDa})
\end{array}
$$

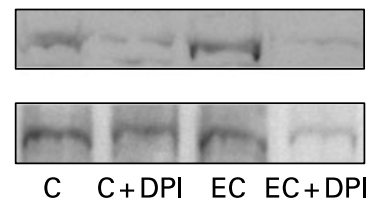

(C)

$$
240 \min \mid \begin{aligned}
& \text { Nrf2 (cyt, } 57 \mathrm{kDa} \text { ) } \\
& \text { Nrf2 (nuc, 57 kDa) }
\end{aligned}
$$$$
1080 \min \mid \begin{aligned}
& \text { Nrf2 (cyt, } 57 \mathrm{kDa}) \\
& \text { Nrf2 (nuc, 57 kDa) }
\end{aligned}
$$

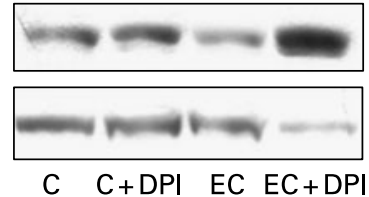

(E)

$$
240 \min \mid \begin{aligned}
& N F-\kappa B \text { (cyt) } \\
& N F-\kappa B \text { (nuc) }
\end{aligned}
$$

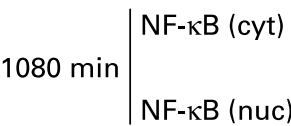

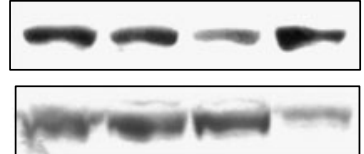

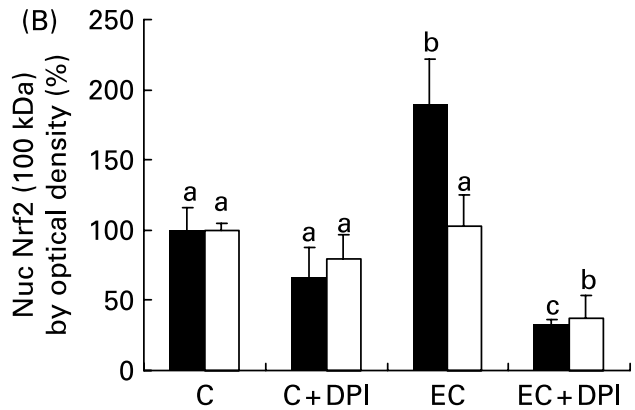

(D)
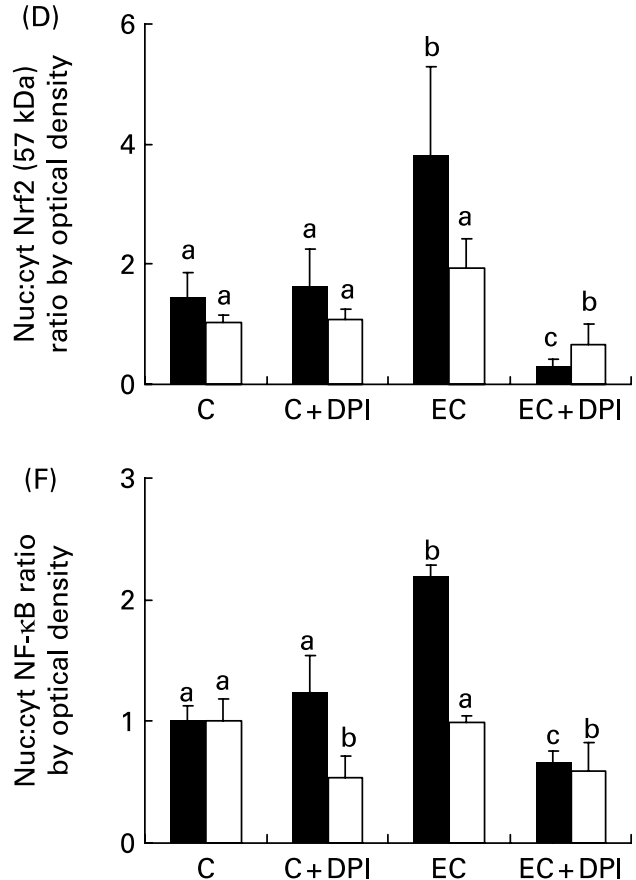

Fig. 8. Effects of epicatechin (EC) and diphenyleneiodonium (DPI) on cytosolic (cyt) and nuclear (nuc) nuclear transcription factor erythroid $2 \mathrm{p} 45$-related factor-2 (Nrf2) (100 and $57 \mathrm{kDa}$ ) and NF-kB levels. HepG2 cells were incubated with or without $10 \mu \mathrm{M}-\mathrm{EC}$ for 240 or $1080 \mathrm{~min}$ in the presence or absence of $20 \mu \mathrm{M}-\mathrm{DPI}$. (A, C, E) Bands of representative experiments. Anti-growth factor receptor-bound protein-2 (anti-GRB2) and anti-poly(ADPribose)polymerase (anti-PARP) antibodies, used as markers for the cyt and nuc extracts, respectively, were not included in the plots due to the complexity of the figures. (B) Percentage of $100 \mathrm{kDa}$ nuc Nrf2 relative to the control (C) condition after $240(\square)$ and $1080(\square)$ min of incubation in the presence or absence of DPI, determined by densitometric quantification. Values are means $(n 5-6)$, with standard deviations represented by vertical bars. ${ }^{\mathrm{a}, \mathrm{b}, \mathrm{c}}$ Mean values (for the 240 or 1080 min condition) with unlike letters were significantly different $(P<0.05)$. (D) Nuc:cyt Nrf2 $(57 \mathrm{kDa})$ ratio after $240(\square)$ and $1080(\square)$ min of incubation in the presence or absence of DPI, determined by densitometric quantification. Values are means $(n 5-6)$, with standard deviations represented by vertical bars. ${ }^{\mathrm{a}, \mathrm{b}, \mathrm{c}}$ Mean values (for the 240 or 1080 min condition) with unlike letters were significantly different $(P<0 \cdot 05)$. (F) Nuc:cyt NF-kB ratio after $240(\square)$ and $1080(\square)$ min of incubation in the presence or absence of $\mathrm{DPI}$, determined by densitometric quantification. Values are means $(n 5-6)$, with standard deviations represented by vertical bars. ${ }^{\mathrm{a}, \mathrm{b}, \mathrm{c}} \mathrm{Mean}$ values (for the 240 or 1080 min condition) with unlike letters were significantly different $(P<0.05)$.

to promote cell survival because of the ability of the $c$-jun amino-terminal kinase signalling pathway to induce survival or apoptosis depending on the cellular context ${ }^{(14,15)}$. Accordingly, the increased AP-1 activity and nuclear c-Jun levels induced by epicatechin have been shown to be coordinated with the enhanced nuclear NF- $\mathrm{B}$ levels, as well as with the activation of different key survival and proliferation signals, in agreement with previous results ${ }^{(4,5)}$. However, other authors have reported that epicatechin treatment of a human colon cell line did not modify c-Jun levels, in accordance with an AP-1 activity similar to controls ${ }^{(47)}$.

$\mathrm{Nrf} 2$ is closely involved in the modulation of the antioxidant defence system, as well as in cell survival and proliferation $^{(11,50)}$. In line with this, it has been demonstrated that polyphenols alone could activate $\operatorname{Nrf} 2^{(23,49)}$, which is in agreement with the present study. Phosphorylated Nrf2 $(100 \mathrm{kDa})$ was not detected in the cytosolic fractions of HepG2 cells, as previously shown ${ }^{(19)}$. Nrf2 phosphorylation has been described as a critical event for the nuclear translocation of this transcription factor, as well as for its transcriptional activity ${ }^{(19,20)}$; this last feature could be related to the nuclear phosphorylated Nrf2 levels described in the present study. In this context, it is interesting to note that the activation of Nrf2 and NF- $\mathrm{NB}$ could be modulated by ROS, MAPK (ERK), protein kinase C and PI3K ${ }^{(11,17,19,20)}$.

ROS seem to play an important role in Nrf2 and NF-кB activation, since low ROS levels induce Nrf2, whereas an intermediate amount of ROS trigger the activation of NF-кB and a high level of oxidative stress could result in apoptosis or necrosis ${ }^{(51)}$. Previously, we have shown that epicatechin 
(A)

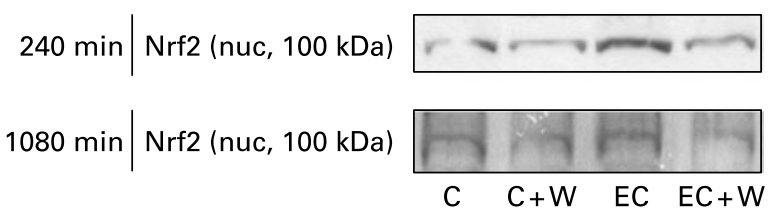

(C) $240 \min \mid \begin{aligned} & \text { Nrf2 (cyt, } 57 \mathrm{kDa}) \\ & \text { Nrf2 (nuc, 57 kDa) }\end{aligned}$

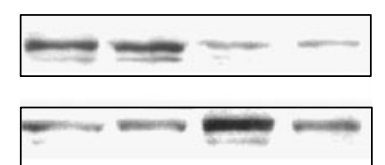
$1080 \min \mid \begin{aligned} & \text { Nrf2 (cyt, } 57 \mathrm{kDa}) \\ & \text { Nrf2 (nuc, } 57 \mathrm{kDa} \text { ) }\end{aligned}$

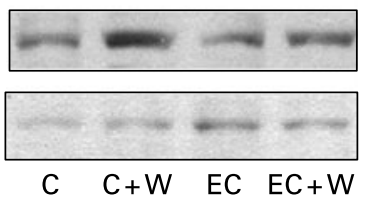

(E) $240 \min \mid \begin{aligned} & N F-\kappa B \text { (cyt) } \\ & N F-\kappa B \text { (nuc) }\end{aligned}$ $1080 \min \mid \begin{aligned} & \text { NF- } \kappa B \text { (cyt) } \\ & N F-\kappa B \text { (nuc) }\end{aligned}$
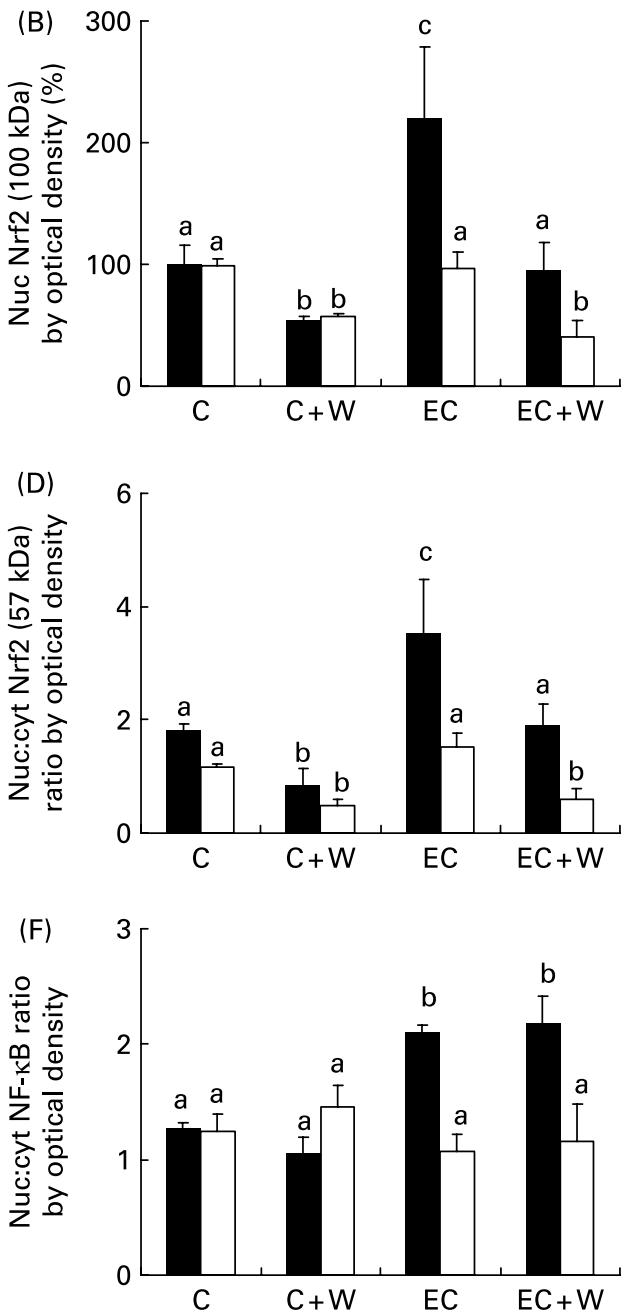

Fig. 9. Effects of epicatechin (EC) and wortmannin (W) on cytosolic (cyt) and nuclear (nuc) nuclear transcription factor erythroid 2p45-related factor-2 (Nrf2) (100 and $57 \mathrm{kDa}$ ) and NF-kB levels. HepG2 cells were incubated with or without $10 \mu \mathrm{M}-\mathrm{EC}$ for 240 or $1080 \mathrm{~min}$ in the presence or absence of $200 \mathrm{nM}-\mathrm{W}$. (A, C, E) Bands of representative experiments. Anti-growth factor receptor-bound protein-2 (anti-GRB2) and anti-poly(ADPribose)polymerase (anti-PARP) antibodies, used as markers for the cyt and nuc extracts, respectively, were not included in the plots due to the complexity of the figures. (B) Percentage of $100 \mathrm{kDa}$ nuc Nrf2 relative to the control (C) condition after $240(\square)$ and $1080(\square)$ min of incubation in the presence or absence of W, determined by densitometric quantification. Values are means $(n 5-6)$, with standard deviations represented by vertical bars. ${ }^{a, b}$ Mean values (for the 240 or 1080 min condition) with unlike letters were significantly different $(P<0.05)$. (D) Nuc:cyt Nrf2 $(57 \mathrm{kDa})$ ratio after $240(\square)$ and $1080(\square)$ min of incubation in the presence or absence of W, determined by densitometric quantification. Values are means ( $n 5-6)$, with standard deviations represented by vertical bars. ${ }^{\mathrm{a}, \mathrm{b}}$ Mean values (for the 240 or 1080 min condition) with unlike letters were significantly different $(P<0.05)$. (F) Nuc:cyt NF-KB ratio after 240 ( $\square)$ and 1080 ( $\square)$ min of incubation in the presence or absence of W, determined by densitometric quantification. Values are means $(n 5-6)$, with standard deviations represented by vertical bars. ${ }^{\mathrm{a}, \mathrm{b}}$ Mean values (for the 240 or 1080 min condition) with unlike letters were significantly different $(P<0.05)$.

treatment $(10 \mu \mathrm{M})$ causes a transient decrease of ROS (starting at $30 \mathrm{~min}$ ) in HepG2 cells ${ }^{(5)}$. In this regard, it has been reported that attenuation of ROS release by natural antioxidant compounds is accompanied by increased Nrf2 accumulation in the nucleus and increased transcriptional activity of $\mathrm{Nrf} 2^{(52)}$; in addition, a transient modification of ROS production could result in the modulation of genes related to oxidative stress defence, as well as survival and proliferation signals in HepG2 cells ${ }^{(53)}$ and a blocked ROS production in HepG2 cells inhibited Nrf2-induced expression and nuclear translocation ${ }^{(53)}$. Thus, these results suggest the importance of intracellular ROS levels for epicatechin-induced Nrf2 and NF-кB activation in HepG2 cells.

Activation of $\mathrm{Nrf} 2$ and $\mathrm{NF}-\kappa \mathrm{B}$ involves regulation of protein kinases ${ }^{(17,23,54)}$, which may induce their nuclear translocation, as well as Nrf2 phosphorylation ${ }^{(20)}$. We have previously shown that epicatechin treatment $(10 \mu \mathrm{M})$ induces cellular survival by activating key kinases in HepG 2 cells ${ }^{(5)}$. In this regard, specific protein kinase inhibitors of PI3K and ERK repressed Nrf2 phosphorylation and nuclear translocation of Nrf2 and NF-кB in HepG2 untreated cells, as previously reported in different cell types ${ }^{(19,23,54-56)}$. These findings point out that $\mathrm{PI} 3 \mathrm{~K} / \mathrm{AKT}$ and/or ERK signalling pathways are required for $\mathrm{Nrf} 2$ and $\mathrm{NF}-\kappa \mathrm{B}$ activation in HepG2 cells. The present results also suggest that the ERK pathway plays a role in the epicatechin-induced activation of phosphorylation and nuclear translocation of $\mathrm{Nrf} 2$ and $\mathrm{NF}-\kappa \mathrm{B}$ and that the PI3K/AKT pathway does not significant affect NF-кB. Reduction of NF- $\mathrm{B}$ activation by the inhibition of the ERK pathway has also been reported on the NF- $\kappa B$ pathway 
(A)

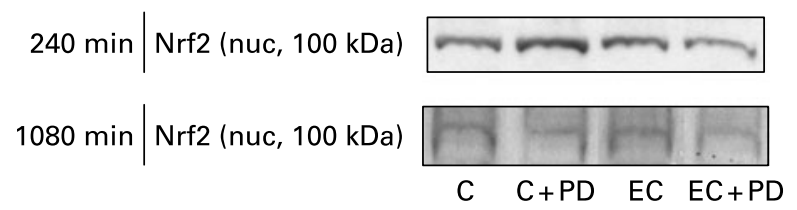

(C)

$$
240 \min \mid \begin{aligned}
& \text { Nrf2 (cyt, } 57 \mathrm{kDa} \text { ) } \\
& \text { Nrf2 (nuc, 57 kDa) }
\end{aligned}
$$$$
1080 \min \mid \begin{aligned}
& \text { Nrf2 (cyt, } 57 \mathrm{kDa}) \\
& \text { Nrf2 (nuc, } 57 \mathrm{kDa})
\end{aligned}
$$

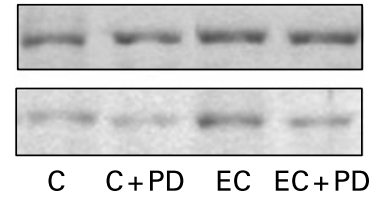

(E)

$$
240 \min \mid \begin{aligned}
& N F-\kappa B \text { (cyt) } \\
& N F-\kappa B \text { (nuc) }
\end{aligned}
$$$$
1080 \min \mid \begin{aligned}
& \text { NF- } \kappa B \text { (cyt) } \\
& \text { NF- } \kappa B \text { (nuc) }
\end{aligned}
$$

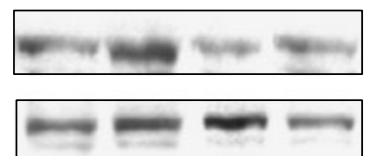

C $\quad C+P D \quad E C \quad E C+P D$

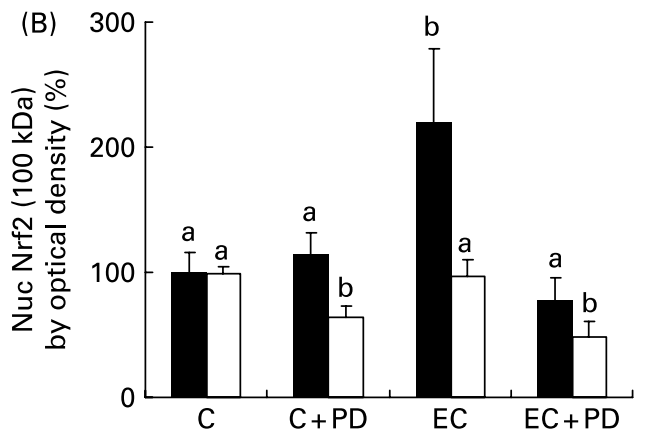

(D)

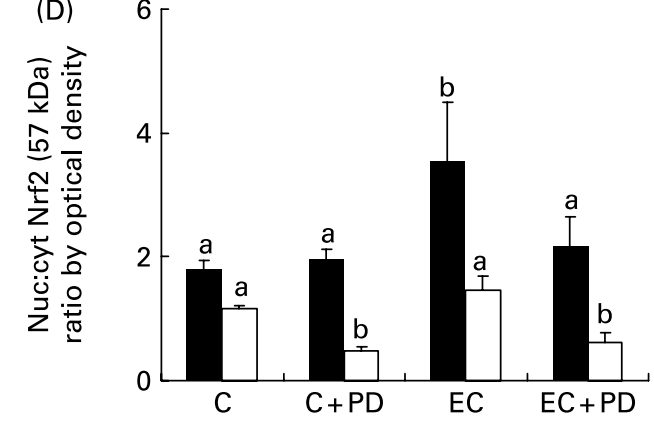

(F)

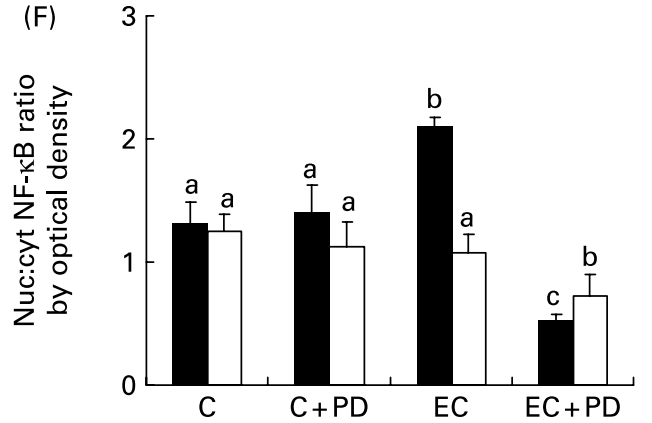

Fig. 10. Effects of epicatechin (EC) and 2-(2-amino-3-methoxyphenyl)-4H-1-benzopyran-4-one (PD98059; PD) on cytosolic (cyt) and nuclear (nuc) nuclear transcription factor erythroid 2p45-related factor-2 (Nrf2) (100 and $57 \mathrm{kDa}$ ) and NF-kB levels. HepG2 cells were incubated with or without $10 \mu \mathrm{M}-\mathrm{EC}$ for 240 or $1080 \mathrm{~min}$ in the presence or absence $50 \mu \mathrm{M}$-PD. (A, C, E) Representative blots. Anti-growth factor receptor-bound protein-2 (anti-GRB2) and anti-poly(ADPribose)polymerase (anti-PARP) antibodies, used as markers for the cyt and nuc extracts, respectively, were not included in the plots due to the complexity of the figures. (B) Percentage of $100 \mathrm{kDa}$ nuc Nrf2 relative to the control (C) condition after 240 ( $\square$ ) and $1080(\square)$ min of incubation in the presence or absence of PD, determined by densitometric quantification. Values are means $(n 5-6)$, with standard deviations represented by vertical bars. ${ }^{\text {a,b }}$ Mean values (for the 240 or 1080 min condition) with unlike letters were significantly different $(P<0.05)$. (D) Nuc:cyt Nrf2 (57 kDa) ratio after 240 ( $\square$ ) and 1080 ( $\square)$ min of incubation in the presence or absence of PD, determined by densitometric quantification. Values are means $(n 5-6)$, with standard deviations represented by vertical bars. ${ }^{\mathrm{a}, \mathrm{b}}$ Mean values (for the 240 or 1080 min condition) with unlike letters were significantly different $(P<0.05)$. (F) Nuc:cyt NF-kB ratio after $240(\square)$ and $1080(\square)$ min of incubation in the presence or absence of $\mathrm{PD}$, determined by densitometric quantification. Values are means $(n 5-6)$, with standard deviations represented by vertical bars. a,b,c Mean values (for the 240 or 1080 min condition) with unlike letters were significantly different $(P<0.05)$.

stimulated with $\mathrm{TNF}^{(57)}$. Additionally, it should be mentioned that increased PI3K/AKT activity has been linked to the activation of $\mathrm{Nrf} 2^{(23,52,56,58)}$ and to an enhanced transcriptional activity of NF- $\kappa \mathrm{B}$ in different cell types ${ }^{(54,55)}$, although in our model AKT seems not to be connected to NF- $\kappa \mathrm{B}$ activation. However, an unchanged AKT expression along with inhibited $\mathrm{NF}-\kappa \mathrm{B}$ activation have been reported previously in cells exposed to ionising stimuli ${ }^{(48)}$. Thus, modulation of Nrf2 and NF- $\mathrm{B}$ nuclear translocation by PI3K/AKT and ERK reinforces the idea that both transcription factors exert critical and supporting functions in the regulation of hepatocyte survival and proliferation pathways. Importantly, it has been suggested that the role of each pathway in the regulation of these transcription factors (Nrf2 and NF-кB) and their molecular targets might be specific to the nature of the stimuli and cell type ${ }^{(48,49)}$.

In summary, new insights are provided into the relative contribution of epicatechin on major transcription factors associated with cell survival and proliferation pathways in HepG2 cells. Epicatechin early activates the NF-кB pathway by modulating NF- $\kappa \mathrm{B}$-related proteins, as well as the AP-1 route via nuclear accumulation of c-Jun. The induction of the redox-sensitive transcription factor NF- $\mathrm{BB}$ was connected to ERK, which are involved in the control of hepatic cell survival and proliferation. Similarly, Nrf2 was activated at an early time by the flavonoid and modulated by PI3K/ AKT and ERK pathways. All these features provide evidence for a role of epicatechin in the promotion of cell protection and survival pathways. 


\section{Acknowledgements}

The present study was supported by the grants AGL2004-302, AGL2007-64042 and CSD2007-00063 from the Spanish Ministry of Science and Innovation (CICYT) and 200870 I198 (CSIC). A. B. G.-S. is a predoctoral fellow of the Spanish Ministry of Science and Education. The authors thank Dr de Bosscher and Ine Vanherpe for their expert assistance with the immunofluorescence technique.

A. B. G.-S. participated in culturing HepG2 cells, performing Western blots, electrophoretic mobility shift assays and immunofluorescence assays, and in drafting and revising the manuscript. M. A. M. participated in culturing HepG2 cells, electrophoretic mobility shift assays and in revising the manuscript. G. H. participated in the supervision of the immunofluorescence analysis, and in critical review of and revision of the manuscript. L. G. and L. B. participated in the study design and critical review of and revision of the manuscript. S. R. participated in Western blot and electrophoretic mobility shift assays, study design and coordination, supervision of experimental conduct and analysis, drafting and revision of the manuscript, and approved the final version.

The authors declare that there are no conflicts of interest.

\section{References}

1. Ramos S (2007) Effects of dietary flavonoids on apoptotic pathways related to cancer chemoprevention. J Nutr Biochem $\mathbf{1 8}$, 427-442.

2. Azam S, Hadi N, Khan NU, et al. (2004) Prooxidant property of green tea polyphenols epicatechin and epigallocatechin-3gallate: implications for anticancer properties. Toxicol in Vitro 18, 555-561.

3. Chen L, Yang X, Jiao H, et al. (2002) Tea catechins protect against lead-induced cytotoxicity, lipid peroxidation, and membrane fluidity in HepG2 cells. Toxicol Sci 69, 149-156.

4. Granado-Serrano AB, Martín MA, Izquierdo-Pulido M, et al. (2007) Molecular mechanisms of (-)-epicatechin and chlorogenic acid on the regulation of the apoptotic and survival/ proliferation pathways in a human hepatoma cell line. J Agric Food Chem 55, 2020-2027.

5. Granado-Serrano AB, Martín MA, Goya L, et al. (2009) Timecourse regulation of survival pathways by epicatechin on HepG2 cells. J Nutr Biochem 20, 115-124.

6. D'Archivio M, Filesi C, Di Benedetto R, et al. (2007) Polyphenols, dietary sources and bioavailability. Ann Ist Super Sanita 43, 348-361.

7. Manach C, Scalbert A, Morand C, et al. (2004) Polyphenols: food sources and bioavailability. Am J Clin Nutr 79, 727-747.

8. Kim CH, Kang SU, Pyun J, et al. (2008) Epicatechin protects auditory cells against cisplatin-induced death. Apoptosis 13, 1184-1194.

9. Noé V, Peñuelas S, Lamuela-Raventós RM, et al. (2004) Epicatechin and a cocoa polyphenolic extract modulate gene expression in human Caco-2 cells. J Nutr 134, 2509-2516.

10. Williams RJ, Spencer JP \& Rice-Evans C (2004) Flavonoids: antioxidants or signalling molecules? Free Radic Biol Med 36, $838-849$.

11. Gopalakrishnan A \& Tony Kong AN (2008) Anticarcinogenesis by dietary phytochemicals: cytoprotection by Nrf2 in normal cells and cytotoxicity by modulation of transcription factors NF- $\mathrm{BB}$ and AP-1 in abnormal cancer cells. Food Chem Toxicol 46, 1257-1270.

12. Shaulian E \& Karin M (2002) AP-1 as regulator of cell life and death. Nat Cell Biol 4, E131-E136.
13. Naugler WE \& Karin M (2008) NF-кB and cancer-identifying targets and mechanisms. Curr Opin Genet Dev 18, 1-8.

14. Czaja MJ (2003) The future of GI and liver research: Editorial perspectives III. JNK/AP-1 regulation of hepatocyte death. Am J Physiol Gastrointest Liver Physiol 284, G875-G879.

15. Hess J, Angel P \& Schorpp-Kistner M (2004) AP-1 subunits: quarrel and harmony among siblings. J Cell Sci 117, 5965-5973.

16. Kwon KH, Barve A, Yu S, et al. (2007) Cancer chemoprevention by phytochemicals: potential molecular targets, biomarkers and animal models. Acta Pharmacol Sin 28, 1409-1421.

17. Chen C \& Tony Kong AN (2005) Dietary cancer-chemopreventive compounds: from signaling and gene expression to pharmacological effects. Trends Pharmacol Sci 26, 318-326.

18. Hara H (2007) Molecular mechanism of neuroprotective drugs against oxidative stress-induced neuronal cell death (article in Japanese). Yakugaku Zasshi 127, 1199-1205.

19. Nguyen T, Sherratt PJ, Huang HC, et al. (2003) Increased protein stability as a mechanism that enhances Nrf2-mediated transcriptional activation of the antioxidant response element. $J$ Biol Chem 278, 4536-4541.

20. Pi J, Bai Y, Reece JM, et al. (2007) Molecular mechanism of human Nrf2 activation and degradation: role of sequential phosphorylation by protein kinase CK2. Free Radic Biol Med 42, 1797-1806.

21. Shen G, Jeong WS, Hu R, et al. (2005) Regulation of Nrf2, NF- $\mathrm{B}$, and AP-1 signaling pathways by chemopreventive agents. Antiox Redox Signal 7, 1648-1663.

22. Chung JY, Huang C, Meng X, et al. (1999) Inhibition of activator protein 1 activity and cell growth by purified green tea and black tea polyphenols in H-ras-transformed cells: structureactivity relationship and mechanisms involved. Cancer Res 59, 4610-4617.

23. Bahia PK, Rattray M \& Williams RJ (2008) Dietary flavonoid (-)epicatechin stimulates phosphatidylinositol 3-kinasedependent anti-oxidant response element activity and up-regulates glutathione in cortical astrocytes. $J$ Neurochem 106, 2194-2204.

24. Mackenzie GF \& Oteiza PI (2006) Modulation of transcription factor NF-кB in Hodgkin's lymphoma cell lines: effect of (-)epicatechin. Free Radic Res 40, 1086-1094.

25. Mackenzie GG, Adamo AM, Decker NP, et al. (2008) Dimeric procyanidin B2 inhibits constitutively active NF- $\mathrm{B}$ in Hodgkin's lymphoma cells independently of the presence of IкB mutations. Biochem Pharmacol 75, 1461-1471.

26. Kim MJ, Ryu GR, Kang JH, et al. (2004) Inhibitory effects of epicatechin on interleukin- $1 \beta$-induced inducible nitric oxide synthase expression in RINm5F cells and rat pancreatic islets by down-regulation of NF- $\mathrm{B}$ activation. Biochem Pharmacol 68, $1775-1785$.

27. Mackenzie GG, Carrasquedo F, Delfino JM, et al. (2004) Epicatechin, catechin, and dimeric procyanidins inhibit PMA-induced $\mathrm{NF}-\kappa \mathrm{B}$ activation at multiple steps in Jurkat T cells. FASEB $J$ 18, 167-169.

28. Fabregat I, Herrera B, Fernandez M, et al. (2000) Epidermal growth factor impairs the cytochrome $\mathrm{C} /$ caspase-3 apoptotic pathway induced by transforming growth factor $\beta$ in rat fetal hepatocytes via a phosphoinositide 3-kinase-dependent pathway. Hepatology 32, 528-535.

29. Wen P \& Locker J (1994) A novel hepatocytic transcription factor that binds to $\alpha$-fetoprotein promoter-linked coupling element. Mol Cell Biol 14, 6616-6626.

30. Pierreux CE, Nicolas FJ \& Hill CS (2000) Transforming growth factor $\beta$-independent shuttling of Smad4 between the cytoplasm and nucleus. Mol Cell Biol 20, 9041-9054.

31. De Bosscher K, Vanden Berghe W, Beck I, et al. (2005) A fully dissociated compound of plant origin for inflammatory gene repression. PNAS 102, 15827-15832. 
32. Gloire G, Dejardin E \& Piette J (2006) Extending the nuclear roles of IкB kinase subunits. Biochem Pharmacol 72, 1081-1089.

33. Nijveldt RJ, van Nood E, van Hoorn DE, et al. (2001) Flavonoids: a review of probable mechanisms of action and potential applications. Am J Clin Nutr 74, 418-425.

34. Wang JF, Schramm DD, Holt RR, et al. (2000) A doseresponse effect from chocolate consumption on plasma epicatechin and oxidative damage. J Nutr 130, 2115S-2119S.

35. Rein D, Lotito S, Holt RR, et al. (2000) Epicatechin in human plasma: in vivo determination and effect of chocolate consumption on plasma oxidation status. $J$ Nutr 130, 2109S-2114S.

36. Henning SM, Niu Y, Lee NH, et al. (2004) Bioavailability and antioxidant activity of tea flavanols after consumption of green tea, black tea, or a green tea extract supplement. Am J Clin Nutr 80, 1558-1564.

37. Baba S, Osakabe $\mathrm{N}$, Natsume $\mathrm{M}$, et al. (2001) In vivo comparison of the bioavailability of $(+)$-catechin, (-)-epicatechin and their mixture in orally administered rats. $J$ Nutr 131, 2885-2891.

38. Basu-Modak S, Gordon MJ, Dobson LH, et al. (2003) Epicatechin and its methylated metabolite attenuate UVA-induced oxidative damage to human skin fibroblats. Free Radic Biol Med 35, 910-921.

39. Spencer J, Schroeter H, Kuhnle G, et al. (2001) Epicatechin and its in vivo metabolite $3^{\prime}$-O-methyl epicatechin, protect human fibroblasts from oxidative-stress-induced cell death involving caspase-3. Biochem J 354, 493-500.

40. Canali R, Ambra R, Stelitano C, et al. (2007) A novel model to study the biological effects of red wine at molecular level. $\mathrm{Br} \mathrm{J}$ Nutr 97, 1053-1058.

41. Luo JL, Tan W, Ricono JM, et al. (2007) Nuclear cytokineactivated IKK $\alpha$ controls prostate cancer metastasis by repressing Maspin. Nature 446, 690-694.

42. Furuya K, Ozaki T, Hanamoto T, et al. (2007) Stabilization of p73 by nuclear IкB kinase- $\alpha$ mediates cisplatin-induced apoptosis. J Biol Chem 282, 18365-18378.

43. Schwabe RF \& Sakurai H (2005) IKK $\beta$ phosphorylates p65 at S468 in transactivaton domain 2. FASEB $J$ 19, 1758-1760.

44. Sakurai H, Chiba H, Miyoshi H, et al. (1999) IкB kinases phosphorylate NF-кB p65 subunit on serine 536 in the transactivation domain. $J$ Biol Chem 274, 30353-30356.

45. Garcia-Mediavilla V, Crespo I, Collado P, et al. (2007) The anti-inflammatory flavones quercetin and kaempferol cause inhibition of inducible nitric oxide synthase, cyclooxygenase-2 and relative C-protein, and down-regulation of the nuclear factor- $\mathrm{kB}$ pathway in Chang liver cells. Eur J Pharmacol 557, $221-229$

46. Jeong WS, Kim IW, Hu R, et al. (2004) Modulation properties of various natural chemopreventive agents on the activation of NF-кB signaling pathway. Pharm Res 21, 661-670.

47. Jeong W-S, Kim I-W, Hu R, et al. (2004) Modulation of AP-1 by natural chemopreventive compounds in human colon HT-29 cancer cell line. Pharm Res 21, 649-660.

48. Kim BY, Kim KA, Kwon O, et al. (2005) NF-кB inhibition radiosensitizes Ki-Ras-transformed cells to ionizing radiation. Carcinogenesis 26, 1395-1403.

49. Lim JH, Park H-S, Choi J-K, et al. (2007) Isoorientin induces Nrf2 pathway-driven antioxidant response through phosphatidylinositol 3-kinase signaling. Arch Pharm Res 30, 1590-1598.

50. Marhenke S, Lamle J, Buitrago-Molina LE, et al. (2008) Activation of nuclear factor E2-related factor 2 in hereditary tyrosinemia type 1 and its role in survival and tumor development. Hepatology 48, 487-496.

51. Gloire G, Legrand-Poels S \& Piette J (2006) NF-кB activation by reactive oxygen species: fifteen years later. Biochem Pharmacol 72, 1493-1505.

52. Hwang YP \& Jeong HG (2008) The coffee diterpene kahweol induces heme oxygenase-1 via the PI3K and p38/Nrf2 pathway to protect human dopaminergic neurons from 6hydroxydopamine-derived oxidative stress. FEBS Lett 582, $2655-2662$.

53. Gong P, Hu B \& Cederbaum AI (2004) Diallyl sulfide induces heme oxygenase-1 through MAPK pathway. Arch Biochem Biophys 432, 252-260.

54. Sethi G, Sung B \& Aggarwal BB (2008) Nuclear factor-кB activation: from bench to bedside. Exp Biol Med 233, 21-31.

55. Kane LP, Shapiro VS, Stokoe D, et al. (1999) Induction of NF- $\kappa$ B by the AKT/PKB kinase. Curr Biol 9, 601-604.

56. Lee J-M, Hanson JM, Chu WA, et al. (2001) Phosphatidylinositol 3-kinase, not extracellular signal-regulated kinase, regulates activation of the antioxidant-responsive element in IMR-32 human neuroblastoma cells. J Biol Chem 276, 20011-20016.

57. Williams LM, Lali F, Willetts K, et al. (2008) Rac mediates TNF-induced cytokine production via modulation of NF-кB. Mol Immunol 45, 2446-2454.

58. Beyer TA, Xu W, Teupser D, et al. (2008) Impaired liver regeneration in Nrf2 knockout mice: role of ROS-mediated insulin/IGF-1 resistance. EMBO J 27, 212-223. 